\title{
Estimate of the Aquifer Temperature of Assammaqieh Well in Akkar by Geothermometric Equations
}

\author{
Abdulrahim Ibrahim \\ Department of Geography (GISRS Lab), Lebanese University, Tripoli, Lebanon \\ Email: abdelrahimibrahim@hotmail.com
}

How to cite this paper: Ibrahim, A. (2017) Estimate of the Aquifer Temperature of Assammaqieh Well in Akkar by Geothermometric Equations. Journal of Water Resource and Protection, 9, 271-288.

https://doi.org/10.4236/jwarp.2017.93018

Received: October 22, 2016

Accepted: February 25, 2017

Published: February 28, 2017

Copyright $\odot 2017$ by author and Scientific Research Publishing Inc. This work is licensed under the Creative Commons Attribution International License (CC BY 4.0).

http://creativecommons.org/licenses/by/4.0/

\begin{abstract}
This research aims at estimating the temperature of the aquifer that supplies Assammaqieh well at the depth of $550 \mathrm{~m}$, on the basis of chemical analyses and geothermometric techniques which are one of the methods used for searching for the renewable geothermal energy and conserving the environment. In this study, about twenty-two geothermometric indicators have been used. For verifying the results, these results have been compared with data and estimates of temperature of fluids of deep typical wells in New Zealand, and it has been noticed that the theoretical and actual results approach the limits of $95 \%$ in many indicators. The study has been restricted to the relations of Cations because they are the most reliable, and the least affected by dissolution and evaporation. Most of the indicators that are based on the four chemical elements: Calcium (Ca), Potassium (K), Sodium ( $\mathrm{Na})$, Magnesium $(\mathrm{Mg})$, have been adopted. The laboratory analysis data of Assammaqieh well confirmed that it was hot sulphurous water that acquired its chemical properties from complicated geochemical conditions, underground thermal conditions and volcanic rock nature. It also turned out that the underground heating process was basically due to thermal conductivity and rock adjacency, and that Assammaqieh well was supplied with water from adjacent groundwater tables whose source was the penetration of surface water. It also appeared that most of the equations used in the search for geothermal energy revealed the presence of an aquifer of hot and very hot water, and they were compatible with the high thermal gradient in volcanic rocks. It also tuned out that $86 \%$ of the used geothermometric equations estimated the aquifer temperature of Assammaqieh well as being hot and very hot with around 135.5 Celsius $( \pm 20)$. The study concluded with the hypothesis that Akkar possessed a huge geothermal energy, and benefiting from this energy might put an end to the chronic problem of electricity in Lebanon, and opened up many prospects and uses that could participate in a sustainable and comprehensive development of Akkar
\end{abstract}


and Lebanon as a whole.

\section{Keywords}

Geothermometry, Geothermal Energy, Aquifer, Temperature, Lebanon

\section{Introduction}

The geothermometric method or the geothermal measurement is one of the most important tools and techniques used in searching for the geothermal energy and estimating the aquifers temperatures, and it is also the easiest and the least expensive. The importance of this technique lies in providing a preliminary idea and an estimate of the groundwater aquifer temperature, regardless of the residual temperature.

So much accuracy and caution are required when applying geothermometry or issuing its results, because they might be tainted by some errors and false results. However, the results of the geothermal measurement are fairly reliable as proved by many studies since they provide an overall and theoretical estimate on the geothermal temperature of hot water. This led us to dwell in the midst of these tools to find an additional and acceptable geochemical indicator or evidence on the presence of geothermal energy in Akkar.

These methods are usually used by specialists in chemistry of fluids or geochemistry because they are an important indicator in the field of searching for geothermal energy. Therefore, we resorted to these methods due to their importance and implication, since they had never been used or adopted in the area, if not in Lebanon as a whole. In order to avoid some special technical obstacles which we had encountered, some specialists in the Chemistry of Water from the Faculty of Public Health in the Lebanese University-Branch Three were hired and consulted. Our purpose behind this work was to confirm the correctness of the path we had taken through studying the geothermal indicators, and we were extremely careful and accurate in issuing the results in our hands. Therefore, our study on this aspect was limited only to the Cations relations because they were more reliable and the least influential on dissolution and evaporation [1]. In Lebanon, the geothermal energy received interest by some researchers, but it did not yet receive adequate concern by the governmental sector. This is mainly attributed to the lack of profound studies about this topic and because the attention was still directed towards the traditional sources of energy being more reliable and provided quick profit. Few studies have dealt with the subject in Lebanon, like in [2]-[8]. These studies are almost general overview and they demonstrate the presence of hot water in Akkar, but no detailed study has yet been conducted to determine and delineate the geothermal potential zones in the region. In this study, our goal is to use geothermometric descriptors in order to estimate the aquifer temperature of Assammaqieh well situated in Akkar, North Lebanon. 


\section{The Importance of Using Geothermometry in Estimating Groundwater Temperature}

The importance of adopting the geothermometric method is based on the correlation of the chemical composition of hot groundwater with the time it spends inside the rocks which it traverses (see methodology page). Among the most important things which are counted upon in this regard are the ratios of the dissolved mineral compounds in this water which has therapeutic uses and properties, and they are: Sodium ( $\mathrm{Na})$, Potassium (K), Calcium (Ca), Magnesium $(\mathrm{Mg})$. This hot water might also contain Carbon Dioxide $\left(\mathrm{CO}_{2}\right)$ and Sulfur Gas $\left(\mathrm{H}_{2} \mathrm{~S}\right)$.

Chemical analysis and isotope analysis are related to the basic processes which affect the chemical composition of hot water [1], and they are summarized as follows:

- The contribution of the atmosphere to water.

- The degree of seawater intrusion.

- Interaction and exchange between water and igneous rocks in a relatively high temperature.

- Admixture of water from different sources.

The chemical analysis of geothermal fluids from hot springs and hot water wells is also useful in the following fields:

- Providing information on the nature of the host rocks.

- Estimating the temperature of groundwater.

- Conceptualizing the history and flow regime of the fluid.

- Optimal utilization of the geothermal resources in the medium and long terms.

- Pre-conceptualizing the possible problems of corrosion and precipitation of metals.

The estimate of the temperature of the original water in the geothermal aquifer might be tainted by some errors due to being admixed with water coming from other various sources, especially surface-layers water which changes the balance between the groundwater and the deep rocks inside the geothermal aquifer. Therefore, the estimates of the aquifer temperature are hypothetical at minimum, and they can't be verified without drilling exploratory (experimental) wells.

\section{Types of Geothermometer and the Balances}

Based on the chemical elements used in the geothermometric equations, they can be classified into four main groups:

The first group is based on Silica $\left(\mathrm{SiO}_{2}\right)$.

The second group is based on alkaline elements [9].

The third group is based on the projection of the simple experiments between a specific metal and a solution, and usually quartz is used [10].

The last group is based on experimental standards derived from the relation between the concentration of Silica of the natural hot water and the temperature of hot springs and wells. 
The quartz, chalcedony and feldspar minerals are characterized by the increase of their solubility when the temperature increases. The deep water maintains the balance while rising to the surface, and it can be used in geothermometric studies [11].

The balance state of an aquifer is based on many factors, the most notably are:

- The kinetics of the interaction among its components.

- The aquifer temperature.

- The type of container rocks and their radioactivity.

- The concentration of the indicated elements in water.

- The time of water stability inside the aquifer in a certain temperature.

As a result, the balance state in the aquifer might sometimes reach some interactions, without the others. On the other hand, the balance or the imbalance of the hot water after leaking into the surface is related to many factors which are:

- Water speed.

- Flow regime.

- Host rock lithology.

- The original temperature of the geothermal aquifer.

- The kinetics of the different possible interactions.

Dissolution and precipitation on the one hand, and ion exchange on the other hand are the most prominent interaction types related to temperature, and useful as a geothermometric quantitative indicator [12].

Due to the nature of the subject and the limited laboratory and material resources, the focus in the study was on a number of traditional geothermometric measures or indicators. Both [13] [14] and [15] presented the measure $\mathrm{Na} / \mathrm{K}$ which is based on the balance between Plagioclase and Feldspar. [16] also emphasized that this measure is particularly useful for the hot groundwater with temperature above $150^{\circ} \mathrm{C}$.

\section{Material and Methods}

During the reference study of this research, some researchers confirmed the presence of several sites (wells and springs) of hot water in Lebanon [7]. There are also indicators of hot water off Abda locality (under the sea) according to airborne thermal infrared survey carried out by CNRS of Lebanon 1997.

Laboratory analysis data of Assammaqieh well confirmed that it is sulphurous hot water. The temperature of the water which was pulled from a pipe heading towards the sea (hundreds of meters away from the well site) reached almost $45^{\circ} \mathrm{C}$.

\section{The Adopted Geothermal Indicators}

Geochemical and laboratory analyses available to us determined the nature and type of the study which focused on the available and possible geothermometric techniques for this purpose. Most indicators which address the following four chemical elements have been adopted:

Calcium (Ca), Potassium (K), Sodium (Na), Magnesium (Mg). The number of 
measures used for this purpose reached twenty-two, and they were adopted and applied on the analysis results of Assammaqieh well.

The most prominent of these measures are represented in Table 1:

- The geothermal measure $(\mathrm{Na} / \mathrm{K})$ which was used by many like [16]-[25]. It is obviously that the last two measures will appear later as the most accurate measures in estimating the temperature of Assammaqieh well.

- The geothermal measure $\left(\mathrm{Mg} / \mathrm{K}^{2}\right.$ (or (K/Mg))) of both [18] and [23].

- The geothermal measuring indicator (Na-K-Ca) put by [9] which is a seeming-

Table 1. The Geothermal Measures Used in the Estimate of the Aquifer Temperature.

\begin{tabular}{|c|c|c|c|c|}
\hline & $\begin{array}{l}\text { Measures of hot } \\
\text { aquifers }\end{array}$ & Author & Equation & Temperature \\
\hline 1 & $\mathrm{Na} / \mathrm{K}$ & $\mathrm{Na} / \mathrm{K}(\mathrm{mol} / \mathrm{l})[17]$ & $\begin{array}{c}\mathrm{T}^{\circ} \mathrm{C}=(908 /(0.7+\mathrm{LOG}(\mathrm{Na} / \mathrm{K})))- \\
273.5\end{array}$ & 131.63 \\
\hline 2 & $\mathrm{Na} / \mathrm{K}$ & $\mathrm{Na} / \mathrm{K}(\mathrm{mol} / \mathrm{l})[19]$ & $\begin{array}{c}\mathrm{T}^{\circ} \mathrm{C}=(1217 /(1.256+\operatorname{LOG}(\mathrm{Na} / \mathrm{K}))) \\
-273.15\end{array}$ & 161.62 \\
\hline 3 & $\mathrm{Na} / \mathrm{K}$ & $\mathrm{Na} / \mathrm{K}(\mathrm{ppm})[20]$ & $\begin{array}{c}\mathrm{T}^{\circ} \mathrm{C}=(1217 /(1.483+\mathrm{LOG}(\mathrm{Na} / \mathrm{K}))) \\
-273.15\end{array}$ & 161.98 \\
\hline 4 & $\mathrm{Na} / \mathrm{K}$ & $\mathrm{Na} / \mathrm{K}(\mathrm{mol})[25]$ & $\begin{array}{c}\mathrm{T}^{\circ} \mathrm{C}=(883 /(0.549+\mathrm{LOG}(\mathrm{Na} / \mathrm{K}))) \\
-273.15\end{array}$ & 148.89 \\
\hline 5 & $\mathrm{Na} / \mathrm{K}$ & $\mathrm{Na} / \mathrm{K}(\mathrm{ppm})[21]$ & $\begin{array}{c}\mathrm{T}^{\circ} \mathrm{C}=(933 /(0.993+\mathrm{LOG}(\mathrm{Na} / \mathrm{K})))- \\
273.15\end{array}$ & 131.29 \\
\hline 6 & $\mathrm{Na} / \mathrm{K}$ & $\mathrm{Na} / \mathrm{K}$ (ppm) [21] & $\begin{array}{c}\mathrm{T}^{\circ} \mathrm{C}=(1319 /(1.699+\mathrm{LOG}(\mathrm{Na} / \mathrm{K}))) \\
-273.15\end{array}$ & 164.64 \\
\hline 7 & $\mathrm{Na} / \mathrm{K}$ & $\mathrm{Na} / \mathrm{K}(\mathrm{ppm})[22]$ & $\begin{array}{c}\mathrm{T}^{\circ} \mathrm{C}=(1178 /(1.2393+ \\
\mathrm{LOG}(\mathrm{Na} / \mathrm{K})))-273.15\end{array}$ & 150.21 \\
\hline 8 & $\mathrm{Na} / \mathrm{K}$ & $\mathrm{Na} / \mathrm{K}$ (ppm) [19] & $\begin{array}{c}\mathrm{T}^{\circ} \mathrm{C}=(855.8 /(0.8573+\log \mathrm{Na} / \mathrm{K}))- \\
273.15\end{array}$ & 121.02 \\
\hline 9 & $\mathrm{Na} / \mathrm{K}$ & $\mathrm{Na} / \mathrm{K}(\mathrm{mol} / \mathrm{l})[23]$ & $\begin{array}{c}\mathrm{T}^{\circ} \mathrm{C}=(1390 /(1.75+\mathrm{LOG}(\mathrm{Na} / \mathrm{K}))) \\
-273.15\end{array}$ & 180.53 \\
\hline 10 & $\mathrm{Na} / \mathrm{K}$ & $\mathrm{Na} / \mathrm{K}(\mathrm{mol} / \mathrm{l})[24]$ & $\begin{array}{c}\mathrm{T}^{\circ} \mathrm{C}=(1390 /(1.52+\mathrm{LOG}(\mathrm{Na} / \mathrm{K}))) \\
-273.15\end{array}$ & 180.62 \\
\hline 11 & $\mathrm{Na} / \mathrm{K}$ & $\mathrm{Na} / \mathrm{K}(\mathrm{mol} / \mathrm{l})[18]$ & $\begin{array}{c}\mathrm{T}^{\circ} \mathrm{C}=(1170 /(1.42+\mathrm{LOG}(\mathrm{Na} / \mathrm{K}))) \\
-273.15\end{array}$ & 121.69 \\
\hline 12 & $\mathrm{Na} / \mathrm{K}$ & $\mathrm{Na} / \mathrm{K}(\mathrm{ppm})[16]$ & $\begin{array}{c}\mathrm{T}^{\circ} \mathrm{C}=(1180 /(1.31+\mathrm{LOG}(\mathrm{Na} / \mathrm{K}))) \\
-273.15\end{array}$ & 154.82 \\
\hline 13 & $\mathrm{Na} / \mathrm{K}$ & $\mathrm{Na} / \mathrm{K}(\mathrm{mol} / \mathrm{l})[18]$ & $\begin{array}{c}\mathrm{T}^{\circ} \mathrm{C}=(1190 /(1.35+\mathrm{LOG}(\mathrm{Na} / \mathrm{K}))) \\
-273.15\end{array}$ & 149.76 \\
\hline 14 & $\mathrm{Na} / \mathrm{K}$ & $\mathrm{Na} / \mathrm{K}(\mathrm{mol} / \mathrm{l})[9]$ & $\begin{array}{c}\mathrm{T}^{\circ} \mathrm{C}=(1217 /(1.483+\log (\mathrm{Na} / \mathrm{K})))- \\
273.15\end{array}$ & 129.00 \\
\hline 15 & $\mathrm{Na} / \mathrm{K}$ & $\mathrm{Na} / \mathrm{K}(\mathrm{mol} / \mathrm{l})[9]$ & $\begin{array}{c}\mathrm{T}^{\circ} \mathrm{C}=(855.6 / 0.8573+\log \mathrm{Na} / \mathrm{K})- \\
273.15\end{array}$ & 120.92 \\
\hline 16 & $\mathrm{~K} / \mathrm{Mg}$ & $\mathrm{K} / \mathrm{Mg}(\mathrm{ppm})[24]$ & $\begin{array}{c}\mathrm{T}^{\circ} \mathrm{C}=(4410 /(14-\mathrm{LOG}((\mathrm{K} 2) / \mathrm{Mg}))) \\
-273.15\end{array}$ & 82.76 \\
\hline 17 & $\mathrm{Mg} / \mathrm{K}^{2}$ & $\mathrm{Mg} / \mathrm{k}^{2}(\mathrm{ppm})[23]$ & $\begin{array}{c}\mathrm{T}^{\circ} \mathrm{C}=(4410 /(13.95+ \\
\left.\mathrm{LOG}\left(\mathrm{Mg} /\left(\mathrm{K}^{2}\right)\right)\right)-273.15\end{array}$ & 84.20 \\
\hline 18 & $\mathrm{Mg} / \mathrm{K}^{2}$ & $\mathrm{Mg} / \mathrm{k}^{2}(\mathrm{~mol} / \mathrm{Kgw})[18]$ & $\begin{array}{c}\mathrm{T}^{\circ} \mathrm{C}=(3000 /(5.84+ \\
\left.\mathrm{LOG}\left(\mathrm{Mg} /\left(\mathrm{K}^{2}\right)\right)\right)-273.15\end{array}$ & 59.17 \\
\hline 19 & $\mathrm{Na} / \mathrm{K}$ & $\mathrm{Na} / \mathrm{k}(\mathrm{mol} / \mathrm{l})[9]$ & $\begin{array}{c}\mathrm{T}^{\circ} \mathrm{C}=(777 /(0.4693+\mathrm{LOG}(\mathrm{Na} / \mathrm{K}))) \\
-273.15\end{array}$ & 112.94 \\
\hline 20 & $\mathrm{Na} / \mathrm{K} / \mathrm{Ca}$ & $\mathrm{Na} / \mathrm{K} / \mathrm{Ca}(\mathrm{mol} / \mathrm{l})[9]$ & $\begin{array}{c}\mathrm{T}^{\circ} \mathrm{C}=(1647 /(\mathrm{LOG}(\mathrm{Na} / \mathrm{K}))+\beta \log (\sqrt{ } \\
\mathrm{Ca} / \mathrm{Na})+2.24)-273.15\end{array}$ & 154.00 \\
\hline 21 & $\mathrm{Na}-\mathrm{K}-\mathrm{Ca}$ & Na-K-Ca [26] & $\begin{array}{c}\mathrm{T}^{\circ} \mathrm{C}=22200 /(64.2-\mathrm{LOG}(\mathrm{Na} / \mathrm{K})+ \\
\left.6.3^{*} \mathrm{LOG}((\sqrt{ } \mathrm{Ca} 2) / \mathrm{Na})\right)-273.15\end{array}$ & 117.01 \\
\hline 22 & $\mathrm{Na}-\mathrm{K}-\mathrm{Ca}$ & Na-K-Ca [26] & $\begin{array}{c}\mathrm{T}^{\circ} \mathrm{C}=1416 /(1.69+\mathrm{LOG}(\mathrm{Na} / \mathrm{K})+ \\
\left.0.055^{\star} \mathrm{LOG}(\sqrt{ } \mathrm{Ca} / \mathrm{Na})\right)-273.15\end{array}$ & 163.19 \\
\hline
\end{tabular}


ly important indicator that helps with the estimate of the geothermal, including the low temperature of water. The geothermal measuring indicator put by [26] poses a new equation different from what [9] presented by the method of least squares, and they concluded that this indicator is based on the interaction resulting from alterations more than the ion exchange among feldspars, which leads to a clear estimate of the dynamic thermal elements of the balance of rock and water.

Depending on the report presented by [1], it was possible to find easier method of calculating the indicator put by [9] by changing the concentration of the basic Cations: Sodium, Potassium and Calcium from milligram to gram to change the results into molality unit.

Some of the fallacies which might encounter these measures are what [27] mentioned, and which give false results if they are applied in different terms and conditions like:

- The continual interactions between rocks and water (dissolution/precipitation), proceeding from the geothermal aquifer to the point of emergence or the appearance of hot water on the surface.

- The difference between the chemical compositions and the chemistry of water from which [9] concluded their indicators that are related to the estimate of the aquifer temperature.

- The presence of acidic water which is rich in sulfur and contains some chlorides.

- The absolute concentration of Calcium in the water which is described to contain carbonate minerals, where the level of the partial pressure of carbon dioxide largely affects the concentration of Calcium, etc.

Therefore, all mentioned factors are significantly affecting the geothermal indicators and the correctness of its estimates. Numerous and significant errors might occur in estimating the geothermal temperature when deep hot water admixes with shallow water [11].

\section{Results and Discussion}

To illustrate the importance of the results of the chemical composition of Assammaqieh well that have been reached, and in order to validate the hypotheses on the aquifer temperature of Assammaqieh well, and to check the theoretical results of the adopted equation which are mentioned in Table 2. These results have been approached and compared with the data and the measurements of fluid temperature from typical deep wells in New Zealand [1] whose temperature and chemical properties are known (especially $\mathrm{K}, \mathrm{Ca}, \mathrm{Na}, \mathrm{Mg}$ ) and their geological formations are similar to the volcanic rocks (i.e. basalt) from which the water of Assammaqieh well emerges.

When applying the adopted measures on this data to calculate the theoretical temperature of the aquifer of these wells whose temperature is practically known, the results were extremely amazing and very close to each other. In many equations the theoretical estimates matched the actual measures by $95 \%$ to $99 \%$. 
Table 2. The data of chemical analyses of the water of Assamqieh Well and some geothermal wells in New Zealand.

\begin{tabular}{|c|c|c|c|c|c|c|c|c|c|c|}
\hline \multirow{2}{*}{$\begin{array}{c}\text { Region } \\
\text { Geologic } \\
\text { formation }\end{array}$} & \multirow{2}{*}{ 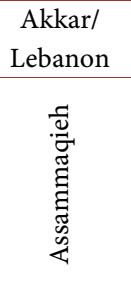 } & \multicolumn{9}{|c|}{ Drillings in New Zealand (measured and calculated temperature in Broadlands ${ }^{\star}$ ) } \\
\hline & & 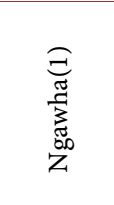 & 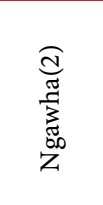 & 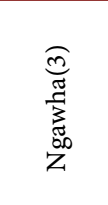 & 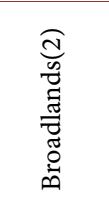 & 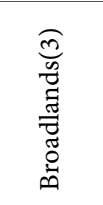 & 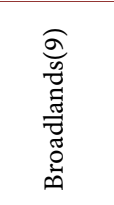 & 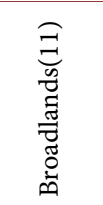 & $\begin{array}{l}\overrightarrow{\tilde{y}} \\
\stackrel{\vec{\pi}}{\vec{\pi}} \\
3\end{array}$ & 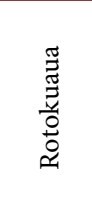 \\
\hline & $\begin{array}{l}. \breve{Z} \\
\frac{\tilde{U}}{0} \\
>\end{array}$ & 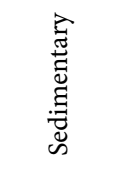 & 矛 & 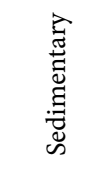 & $\begin{array}{l}. \breve{Z} \\
\stackrel{\tilde{U}}{0} \\
>>\end{array}$ & 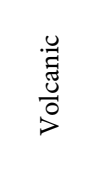 & 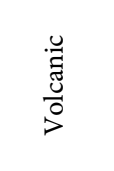 & 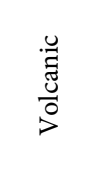 & $\frac{\sum_{0}^{ \pm}}{\frac{\pi}{0}}$ & $\begin{array}{l}. \breve{Z} \\
\frac{\tilde{U}}{0} \\
>0\end{array}$ \\
\hline \multicolumn{11}{|l|}{ Results } \\
\hline $\mathrm{Na}(\mathrm{Mg} / \mathrm{l})$ & 1030 & 900 & 880 & 893 & 1050 & 1045 & 930 & 675 & 1170 & 1525 \\
\hline$K(M g / L)$ & 50 & 78 & 75 & 75 & 210 & 213 & 203 & 130 & 167 & 176 \\
\hline $\mathrm{Ca}(\mathrm{Mg} / \mathrm{L})$ & 218.4 & 29 & 3 & 3 & 2.2 & 3 & 2 & 1 & 20 & 50 \\
\hline$M g(M g / L)$ & 61.5 & 63.5 & 64.5 & 64.5 & 66.5 & 67.5 & 68.5 & 69.5 & 70.5 & 71.5 \\
\hline $\mathrm{Na}(\mathrm{Mol} / \mathrm{kg})$ & 0.045 & 0.039 & 0.038 & 0.038 & 0.046 & 0.045 & 0.04 & 0.029 & 0.051 & 0.066 \\
\hline$K(\mathrm{Mol} / \mathrm{kg})$ & 0.001 & 0.002 & 0.002 & 0.002 & 0.005 & 0.005 & 0.005 & 0.003 & 0.004 & 0.005 \\
\hline $\mathrm{Ca}(\mathrm{Mol} / \mathrm{kg})$ & 0.005 & 0.001 & 0 & 0 & 0 & 0 & 0 & 0 & 0.001 & 0.001 \\
\hline $\operatorname{Mg}(\mathrm{Mol} / \mathrm{kg})$ & 0.003 & 0.003 & 0.003 & 0.003 & 0.003 & 0.003 & 0.003 & 0.003 & 0.003 & 0.003 \\
\hline$\sqrt{C a}$ & 0.074 & 0.027 & 0.009 & 0.009 & 0.007 & 0.009 & 0.007 & 0.005 & 0.022 & 0.035 \\
\hline$\sqrt{\mathrm{Ca}} / \mathrm{Na}$ & 1.650 & 0.688 & 0.226 & 0.223 & 0.162 & 0.191 & 0.175 & 0.17 & 0.44 & 0.533 \\
\hline$\sqrt{C a} / K$ & 57.636 & 13.463 & 4.503 & 4.275 & 1.377 & 1.586 & 1.358 & 1.5 & 5.222 & 7.834 \\
\hline $\operatorname{LOG}(\sqrt{\mathrm{Ca}} / \mathrm{Na})$ & 0.217 & -0.162 & -0.645 & -0.652 & -0.789 & -0.72 & -0.757 & -0.769 & -0.357 & -0.273 \\
\hline $\operatorname{LOG}(\sqrt{C a} / K)$ & 1.761 & 1.129 & 0.654 & 0.631 & 0.139 & 0.2 & 0.133 & 0.176 & 0.718 & 0.894 \\
\hline $\operatorname{LOG}(N a / K)$ & 1.543 & 1.291 & 1.299 & 1.283 & 0.928 & 0.92 & 0.89 & 0.945 & 1.075 & 1.167 \\
\hline$\beta(\beta=4 / 3$ if $\sqrt{C a / N a}$ is positive $)$ & 1.333 & 1.333 & 1.333 & 1.333 & 1.333 & 1.333 & 1.333 & 1.333 & 1.333 & 1.333 \\
\hline$\beta(\beta=1 / 3$ if $\sqrt{\mathrm{Ca} / \mathrm{Na}}$ is negative ) & 0.333 & 0.333 & 0.333 & 0.333 & 0.333 & 0.333 & 0.333 & 0.333 & 0.333 & 0.333 \\
\hline $\mathrm{Na} / K(\mathrm{Mol})$ & 34.93 & 19.565 & 19.896 & 19.167 & 8.478 & 8.319 & 7.768 & 8.804 & 11.88 & 14.692 \\
\hline $\operatorname{LOG}(\mathrm{Na} / K)(\mathrm{Mol})$ & 1.543 & 1.291 & 1.299 & 1.283 & 0.928 & 0.92 & 0.89 & 0.945 & 1.075 & 1.167 \\
\hline$\sqrt{C a}$ & 14.778 & 5.385 & 1.732 & 1.732 & 1.483 & 1.732 & 1.414 & 1 & 4.472 & 7.071 \\
\hline$\sqrt{C a} / K$ & 11527.12 & 2692.58 & 900.67 & 855.06 & 275.46 & 317.14 & 271.7 & 300 & 1044.39 & 1566.9 \\
\hline $\operatorname{LOG}(\sqrt{C a})$ & 1.17 & 0.731 & 0.239 & 0.239 & 0.171 & 0.239 & 0.151 & 0 & 0.651 & 0.89 \\
\hline $\operatorname{LOG}(\sqrt{\mathrm{Ca}} / \mathrm{Na})$ & 26.118 & 18.686 & 6.235 & 6.144 & 3.75 & 5.251 & 3.722 & 0 & 12.79 & 12.812 \\
\hline$\beta \operatorname{LOG}(\sqrt{\mathrm{Ca}} / \mathrm{Na})$ & 34.824 & 24.915 & 8.313 & 8.192 & 5 & 7.001 & 4.963 & 0 & 17.05 & 17.08 \\
\hline $\mathrm{LOGK}^{*}=\operatorname{LOG}(\mathrm{Na} / \mathrm{K})+\beta \operatorname{LOG}(\sqrt{\mathrm{Ca}} / \mathrm{Na})$ & 1.833 & 1.075 & 0.438 & 0.414 & -0.124 & -0.04 & -0.119 & -0.08 & 0.599 & 0.803 \\
\hline $\operatorname{LOG}(\sqrt{\mathrm{Ca}} / \mathrm{Na})+2.24$ & 2.457 & 2.078 & 1.595 & 1.588 & 1.451 & 1.52 & 1.483 & 1.471 & 1.883 & 1.967 \\
\hline$\beta(\operatorname{LOG}(\sqrt{\mathrm{Ca}} / \mathrm{Na})+2.24)$ & 3.277 & 2.77 & 2.126 & 2.118 & 1.934 & 2.027 & 1.977 & 1.962 & 2.511 & 2.623 \\
\hline
\end{tabular}


In other words, the contrast among them did not exceed $1 \%$ to $5 \%$ increase or decrease.

The application of the primary geothermal equations on the laboratory analysis data of Assammaqieh well in Akkar revealed great variation in the estimates of the aquifer temperature. What also boosted our confidence in the correctness of this path is the clear variation in the results and estimates of the aquifer temperature in New Zealand wells according to every geothermometric indicator, although their temperature is actual and known. Thus, it appeared to us that the variation between one indicator and the other in estimating the temperature of Assammaqieh water is normal.

The primary estimates of the temperature of Assammaqieh well (Figure 1) ranged between $59^{\circ} \mathrm{C}$ as a minimum of Michard's equation [18] (based on Magnesium and Potassium), and 181 Celsius with [24] (based on Cations of Sodium and Potassium). This big difference might be caused by the nature of the adopted equations and the rock lithology that contain hot water. On the contrary, we notice that the proximity of the applied and theoretical results in the cases of the hot water in New Zealand is caused by the similarity of the rocks which heat the

$\mathrm{Mg} / \mathrm{k}^{2}(\mathrm{~mol} / \mathrm{Kgw})$ Michard(1990)

k/Mg(ppm) Giggenbach(1988)

$\mathrm{Mg} / \mathrm{k}^{2}(\mathrm{ppm})$ Giggenbach et all.(1983)

$\mathrm{Na} / \mathrm{K}(\mathrm{mol} / \mathrm{l})$ Fournier et truesdell(1973)

Na-K-Ca Benjamin et al.(1983)

$\mathrm{Na} / \mathrm{K}(\mathrm{mol} / \mathrm{l})$ fournier et truesdell 1974(2)

$\mathrm{Na} / \mathrm{K}(\mathrm{ppm})$ fournier 1979

$\mathrm{Na} / \mathrm{K}(\mathrm{mol} / \mathrm{l})$ Michsrd(1990)

$\mathrm{Na} / \mathrm{K}(\mathrm{mol} / \mathrm{l})$ fournier et truesdell 1973(1)

$\mathrm{Na} / \mathrm{K}(\mathrm{ppm})$ ArnÓrsson et all. 1983

$\mathrm{Na} / \mathrm{K}(\mathrm{mol} / \mathrm{l})$ Michard(1979)

$\mathrm{Na} / \mathrm{K}(\mathrm{mol})$ Tanani 1980

$\mathrm{Na} / \mathrm{K}(\mathrm{mol} / \mathrm{l})$ Michard(1990)

$\mathrm{Na} / \mathrm{K}(\mathrm{ppm}) \mathrm{Nieva}$ et Nieva et all. 1987

$\mathrm{Na} / \mathrm{K} / \mathrm{Ca}$ (mol/l) Fournier et Truesdell 1973

$\mathrm{Na} / \mathrm{K}(\mathrm{ppm})$ Kharaka et Mariner(1989)

$\mathrm{Na} / \mathrm{K}(\mathrm{mol} / \mathrm{l})$ fournier 1979

$\mathrm{Na} / \mathrm{K}(\mathrm{ppm})$ fournier 1980

Na-K-Ca Benjamin et al.(1983)

$\mathrm{Na} / \mathrm{K}(\mathrm{ppm})$ ArnÓrsson et all. 1984

$\mathrm{Na} / \mathrm{K}(\mathrm{mol} / \mathrm{l})$ Giggenbach et all.(1983)

$\mathrm{Na} / \mathrm{K}(\mathrm{mol} / \mathrm{l})$ Giggenbach et all.(1988)

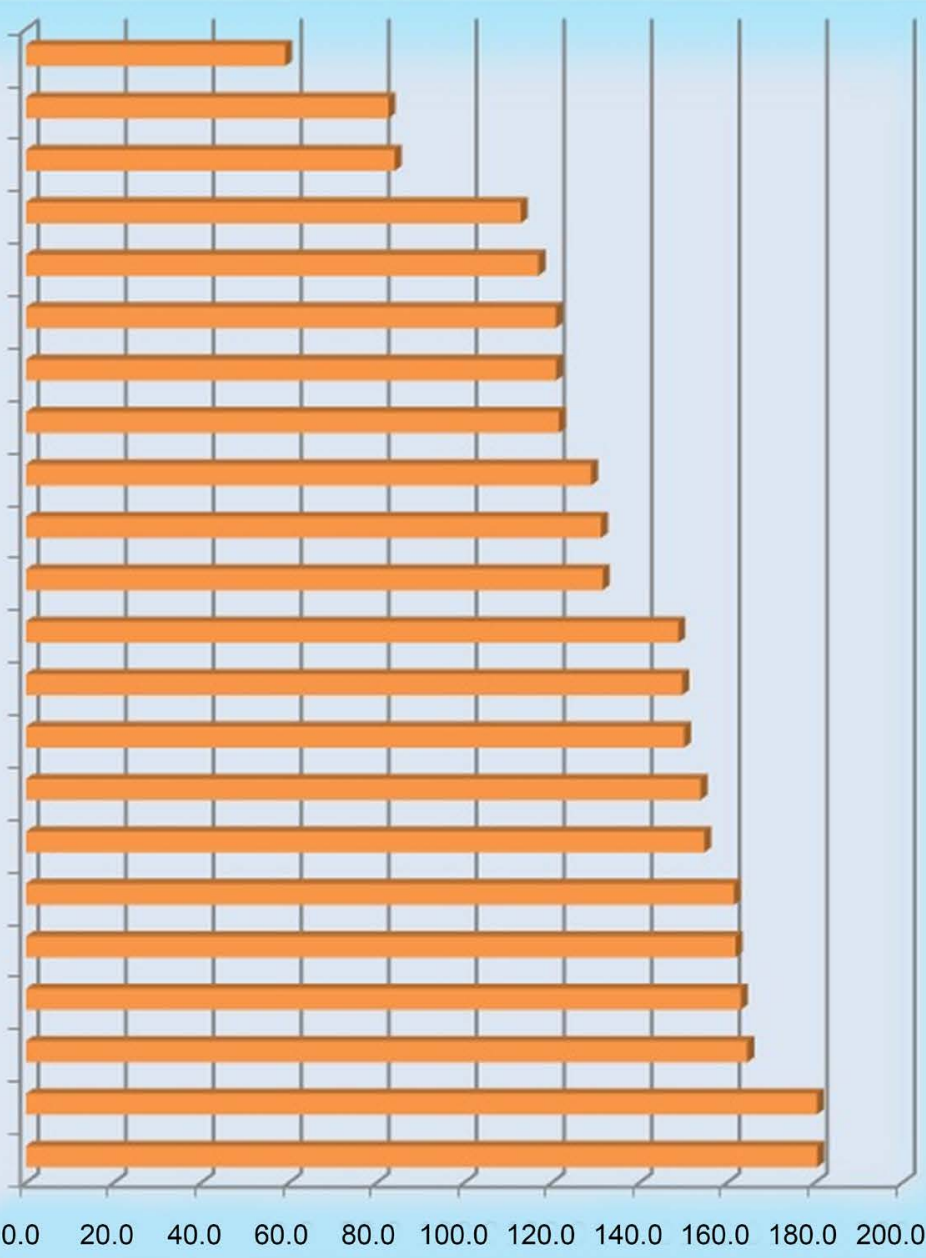

Figure 1. Estimates of the aquifer temperature of Assammaqieh well (according to the adopted measures). 
hot groundwater, and which are semi-permeable basalt rocks.

Since Assammaqieh well contains high ratio of sulfur, we could confirm that Assammaqieh water had been heated in layers of hot basalt volcanic rocks at considerable depth, which are of the same type as the rocks that heat New Zealand wells. Therefore, we can say that the aforementioned equations which give the closest results between the theoretical and actual data of New Zealand might be the most credible and accurate to estimate the temperature of Assammaqieh well.

It seems that the equations based on the Cations of Magnesium and Potassium estimated the temperature of the aquifer with the least rate, which ranged between $60^{\circ} \mathrm{C}$ and $84^{\circ} \mathrm{C}$ only. On the other hand, estimates reached the threshold of $180^{\circ} \mathrm{C}$ for Cations of Sodium and Potassium.

Proceeding from the mixed results of the estimates of the temperature of Assammaqieh well, we could divide these equations into three main groups (Table 3):

The first group is the geothermometric equations which indicated a medium temperature of Assammaqieh aquifer between $50^{\circ} \mathrm{C}$ and $100^{\circ} \mathrm{C}$, and this is equal to $14 \%$ of the total equations.

The second group is the geothermometric equations which revealed a high temperature ranging between 100 and 150 Celsius, and this is equal to $45 \%$ of the total equations.

The third group is the geothermometric equations which indicated a very high temperature of Assammaqieh aquifer exceeding $150^{\circ} \mathrm{C}$, and this is equal to $41 \%$.

From this division we conclude that $86 \%$ of the geothermometric equations estimated the temperature of Assammaqieh aquifer to be hot or very hot (more than $\left.100^{\circ} \mathrm{C}\right)$.

Under this remarkable contrast between different indicators and equations and another, the average of all equations has been calculated by a structural measure through the arithmetic average of all the geothermometric equations (Table 4).

The results were as follows:

- The water of Assammaqieh aquifer acquired its chemical properties from underground thermal conditions and the nature of the volcanic rocks in depths that are not large and with a temperature of not less than $135^{\circ} \mathrm{C}$.

- It is believed that the thermal conductivity is the basis in heating the groundwater in Akkar region, and especially Assammaqieh well which is supplied with

Table 3. The change in the estimates of Assammaqieh aquifer temperature according to the measure (Geothermometry).

\begin{tabular}{cccc}
\hline Category & $\begin{array}{c}\text { Number of } \\
\text { Measures }\end{array}$ & $\%$ & Cumulative Countdown \\
\hline Medium Temperature $\left(\right.$ from $\left.50^{\circ} \mathrm{C}-100^{\circ} \mathrm{C}\right)$ & 3 & 13.6 & 100.0 \\
Hot water $\left(\right.$ from $\left.100^{\circ} \mathrm{C}-150^{\circ} \mathrm{C}\right)$ & 10 & 45.5 & 86.4 \\
Very hot $\left(\right.$ above $\left.150^{\circ} \mathrm{C}\right)$ & 9 & 40.9 & 40.9 \\
Total & 22 & 100 & - \\
\hline
\end{tabular}


Table 4. A comparison between the actual temperature and the extrapolated temperature of hot water from ten wells in different areas in New Zealand.

\begin{tabular}{cccccc}
\hline Region & Geology & $\begin{array}{c}\text { Extrapolated } \\
\text { Temperature }\end{array}$ & $\begin{array}{c}\text { Actual } \\
\text { registered } \\
\text { Temperature }\end{array}$ & Variations & Percentage \% \\
\hline Ngawha (1) & $\begin{array}{c}\text { Adjacent to } \\
\text { igneous } \\
\text { rocks }\end{array}$ & 188.0 & 225.0 & 37.0 & $83.57 \%$ \\
Ngawha (2) & sedimentary & 190.9 & 230.0 & 39.1 & $83.02 \%$ \\
$\begin{array}{c}\text { Ngawha (3) } \\
\text { Broadlands } \\
(2)\end{array}$ & sedimentary & 193.9 & 230.0 & 36.1 & $84.30 \%$ \\
$\begin{array}{c}\text { Broadlands } \\
(3)\end{array}$ & volcanic & 270.8 & 260.0 & -10.8 & $104.14 \%$ \\
$\begin{array}{c}\text { Broadlands } \\
(9)\end{array}$ & volcanic & 272.0 & 281.0 & 9.0 & $96.80 \%$ \\
$\begin{array}{c}\text { Broadlands } \\
(11)\end{array}$ & volcanic & 279.6 & 294.0 & 14.4 & $95.11 \%$ \\
Wairakei & volc/magm & 232.6 & 240.0 & 7.4 & $96.93 \%$ \\
$\begin{array}{c}\text { Rotokuaua } \\
\text { Assammaqieh }\end{array}$ & volcanic & 213.7 & 220.0 & 6.3 & $97.13 \%$ \\
\hline volcanic & 135.5 & & $\pm 20 \mathrm{C} 115-155$ & \\
\hline
\end{tabular}

water from water table whose source is the surface water penetration, and some major adjacent faults help with this penetration.

- The nature of the semi-permeable volcanic rocks which heat Assammaqieh groundwater should not be deep, and therefore the hot aquifer might not be deep too. The main source of supplying water might be the surrounding mountains like Akkar Mountains or Alawites' Mountains in Syria.

In order to enhance confidence in the research methodology and determine which indicators are the least error, and thus which of them is more acceptable, the theoretical and the actual results of New Zealand have been compared (Figure 2). This is in combination with the purpose of verifying the most accurate equation and geothermal measure in estimating the temperature of Assammaqieh geothermal aquifer, a number of calculations have been performed (Table 5) as follows:

- Calculating the average $(\mu)$.

- The standard deviation ( $\sigma$ ) of the variations of theoretical and actual temperature resulted from applying all geothermal equations.

- Calculating the root mean square error which equals: $A S E=\sqrt{\mu^{2}+\sigma^{2}}$.

This calculation showed that the Nieva and Nieva's equations [22] which are based on Calcium and Potassium clarified the great proximity between the actual values and the theoretical estimates of Assammaqieh aquifer (Figure 1).

Conversely, when approaching the temperature estimates of Assammaqieh well according to every measure and the geothermal calculation error, an opposite positive relationship was noticed between them. The high estimates of Assammaqieh aquifer temperature were generally met by the least temperature error between the theoretical and the actual. This means that the results of Assammaqieh aquifer 


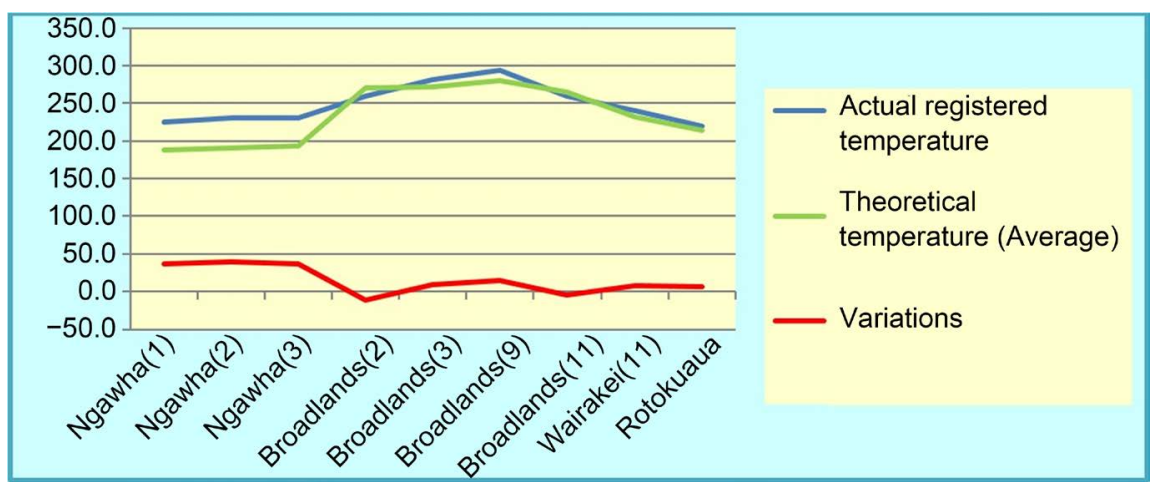

Figure 2. A diagram compares between the actual registered temperature and the theoretical temperature of New Zealand wells.

Table 5. The Root Mean Square Error (RMSE).

\begin{tabular}{|c|c|c|c|c|}
\hline RMSE & Standard deviation & Average & Temperature & Geothermal measure \\
\hline 8.61 & 8.3 & -2.3 & 150.21 & $\mathrm{Na} / \mathrm{K}(\mathrm{ppm})[22]$ \\
\hline 9.4 & 8.32 & -4.37 & 149.76 & $\mathrm{Na} / \mathrm{K}(\mathrm{mol} / \mathrm{l})[18]$ \\
\hline 10.08 & 8.56 & 5.32 & 164.64 & $\mathrm{Na} / \mathrm{K}(\mathrm{ppm})[21]$ \\
\hline 10.2 & 8.32 & 5.9 & 154.82 & $\mathrm{Na} / \mathrm{K}(\mathrm{ppm})[16]$ \\
\hline 10.35 & 10.13 & 2.1 & 131.29 & $\mathrm{Na} / \mathrm{K}(\mathrm{ppm})[21]$ \\
\hline 11.52 & 11.5 & -0.66 & 121.02 & $\mathrm{Na} / \mathrm{K}(\mathrm{ppm})[19]$ \\
\hline 11.52 & 11.5 & -0.79 & 120.92 & $\mathrm{Na} / \mathrm{K}(\mathrm{mol} / \mathrm{l})[9]$ \\
\hline 13.3 & 10.96 & 7.53 & 131.63 & $\mathrm{Na} / \mathrm{K}$ (mol/l) Mirchard (1979) \\
\hline 13.91 & 8.3 & 11.16 & 161.62 & $\mathrm{Na} / \mathrm{K}(\mathrm{mol} / \mathrm{l})[19]$ \\
\hline 14.37 & 8.3 & 11.72 & 161.98 & $\mathrm{Na} / \mathrm{K}$ (ppm) [20] \\
\hline 14.53 & 14.13 & 3.39 & 112.94 & $\mathrm{Na} / \mathrm{K}(\mathrm{mol} / \mathrm{l})[9]$ \\
\hline 18.86 & 12.7 & 13.95 & 154 & $\mathrm{Na} / \mathrm{K} / \mathrm{Ca}(\mathrm{mol} / \mathrm{l})[9]$ \\
\hline 24.25 & 8.51 & 22.71 & 180.53 & $\mathrm{Na} / \mathrm{K}(\mathrm{mol} / \mathrm{l})[23]$ \\
\hline 24.38 & 8.51 & 22.85 & 180.62 & $\mathrm{Na} / \mathrm{K}(\mathrm{mol} / \mathrm{l})[24]$ \\
\hline 40 & 9.16 & -38.94 & 129 & $\mathrm{Na} / \mathrm{K}(\mathrm{mol} / \mathrm{l})[9]$ \\
\hline 46.44 & 9.06 & -45.54 & 121.69 & $\mathrm{Na} / \mathrm{K}(\mathrm{mol} / \mathrm{l})[18]$ \\
\hline 47.04 & 14.83 & 44.64 & 148.89 & $\mathrm{Na} / \mathrm{K}(\mathrm{mol})[25]$ \\
\hline 61.08 & 18.23 & -58.29 & 117.01 & $\mathrm{Na}-\mathrm{K}-\mathrm{Ca}[26]$ \\
\hline 106.31 & 12.5 & 105.57 & 163.19 & {$[26]$} \\
\hline 142.93 & 22.65 & -141.12 & 84.2 & $\mathrm{Mg} / \mathrm{k}^{2}(\mathrm{ppm})[23]$ \\
\hline 144.64 & 22.66 & -142.85 & 82.76 & $\mathrm{~K} / \mathrm{Mg}(\mathrm{ppm})[24]$ \\
\hline 156.96 & 22.26 & -155.37 & 59.17 & $\mathrm{Mg} / \mathrm{k}^{2}(\mathrm{~mol} / \mathrm{K} \cdot \mathrm{gw})[18]$ \\
\hline
\end{tabular}

temperature is consistent with the highest temperature (Category A) which were adopted by [19]-[24] [26], and others (Figure 3).

To define the temperature of Assammaqieh aquifer more accurately, the equations have been divided into three categories, and the most error results between 


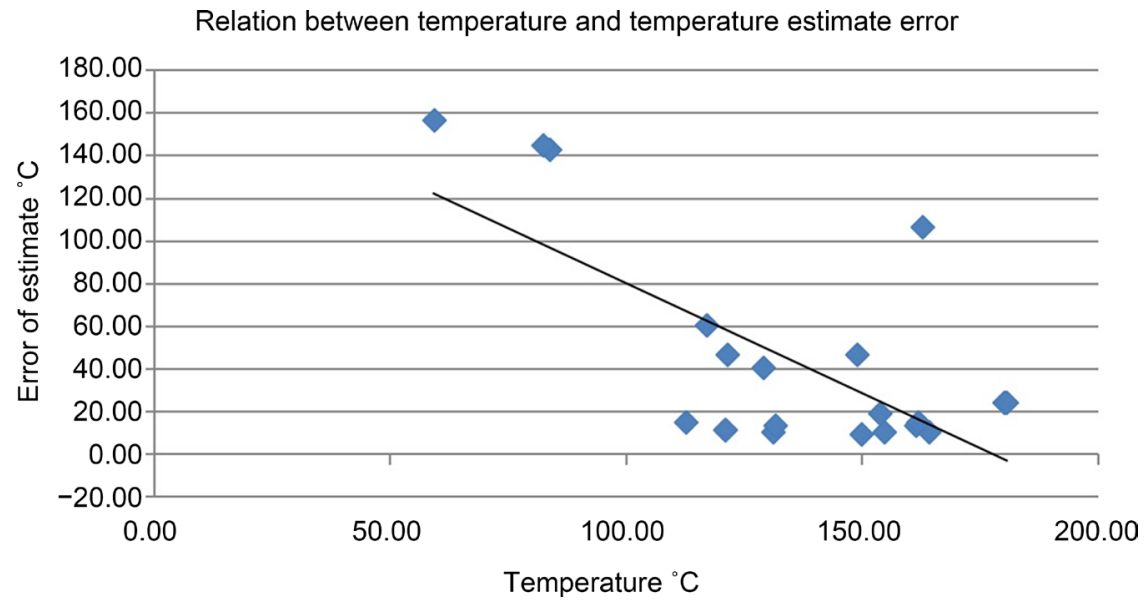

Figure 3. The relation between temperature and temperature estimate error.

the theoretical and actual temperature of categories $\mathrm{C}$ and $\mathrm{B}$ which estimated the average temperature by $129^{\circ} \mathrm{C}$ and $97^{\circ} \mathrm{C}$ successively have been excluded, while category A reached almost $148^{\circ} \mathrm{C}$ (Figure 3).

Accordingly, the estimates of Assammaqieh aquifer temperature tend to rise. So if we calculate the average of the equations with the minimum value in standard deviation, the estimates of Assammaqieh aquifer temperature rise to almost $150^{\circ} \mathrm{C}$. The estimates of Assammaqieh aquifer might range according to dispersion standards (from the least to the most dispersed) according to Figure 4.

Depending on what has been mentioned, it can be said that Assammaqieh aquifer temperature might range between $135.5^{\circ} \mathrm{C}$ and $163^{\circ} \mathrm{C}$. Conversely, some believe that using geothermal equations and measures assume taking into account an increase or decrease of 20 degrees from any theoretical estimate [28]. Studying these geothermal equations, applying the geothermometric method and calculating error rates showed that the error rate does not exceed $14^{\circ} \mathrm{C}(10 \%)$ (Figure 5).

Assuming that Assammaqieh hot water, which is at the depth of $550-650 \mathrm{~m}$ and comes from an aquifer whose water temperature estimate is nearly $135^{\circ} \mathrm{C}$, this means that Assammaqieh aquifer temperature significantly corresponds with the high thermal gradient known in volcanic rock layers, which is $20^{\circ} \mathrm{C}$ to each $100 \mathrm{~m}$ nearly. This number might become very accurate at the faults level and the areas of lava flow.

It is worth mentioning that the temperature beneath Assammaqieh is a residual temperature from lava flow for more than 1.5 million years. Its source might be remote areas through the minor cross-sectional fractures in Akkar Plain situated in Lebanon and Syria (Figure 6(a)). It is believed that the flow of the volcanic lava has started from these faults to cover a big part of Akkar Plain and a wider area of Syria and in Homs area (Figure 6(b)).

If we assume that the thermal gradient of Assammaqieh aquifer is $20^{\circ} \mathrm{C}$ to every $100 \mathrm{~m}$ in volcanic rocks, a one thousand deep well can supply water whose temperature is almost $215^{\circ} \mathrm{C}$. And if we consider that these lavas flowed from a 


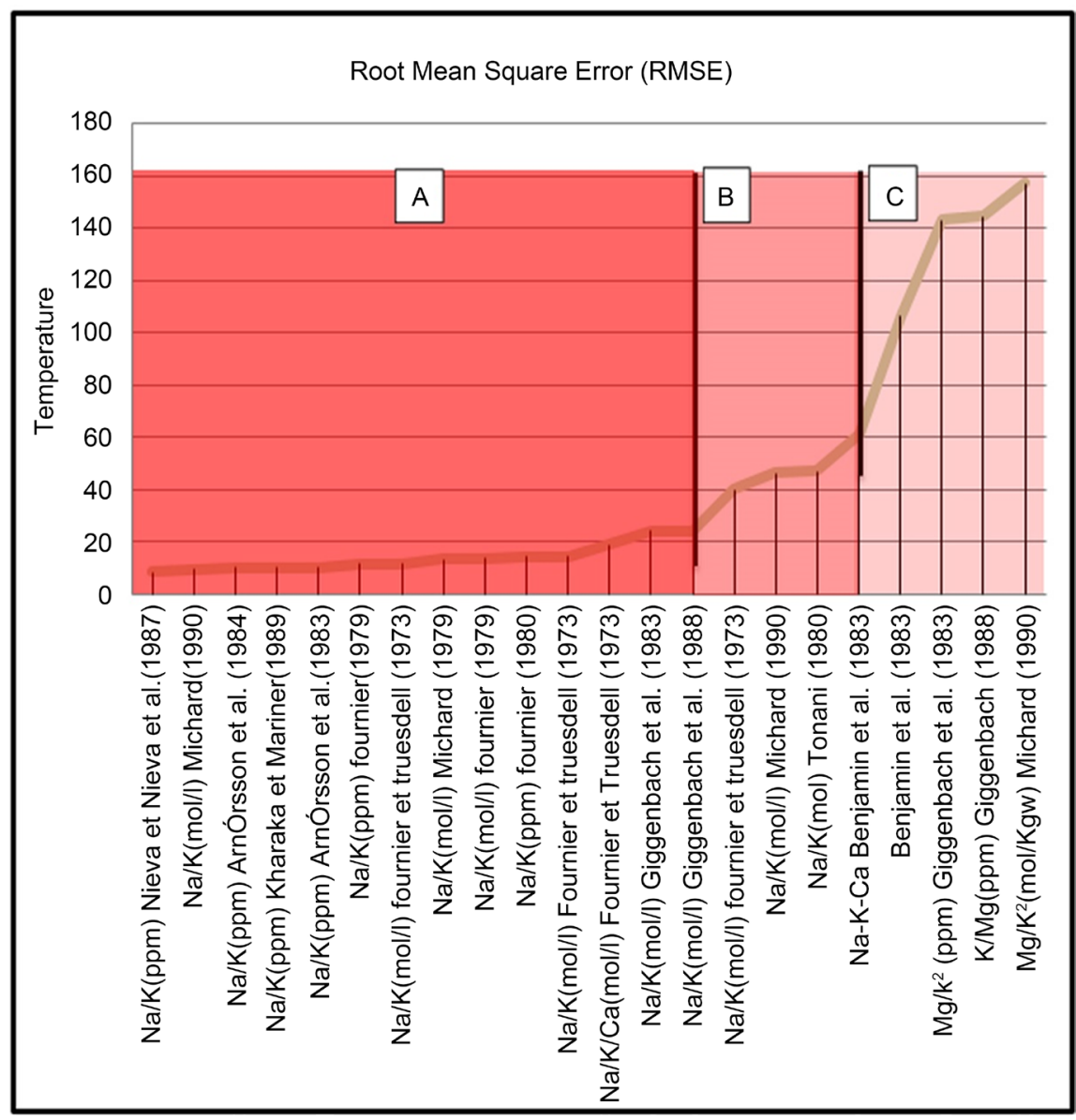

Figure 4. The root mean square error.

main source, from Al-Yammouneh fault; starting from Ouadein valley and Shadra area, then Shadra and Bokeiaa areas might the best suited area to search for geothermal energy and drill exploratory wells (Figure 7).

Nevertheless, these results are just hypotheses that demand a lot of accuracy and advanced technologies, therefore many researchers resort sometimes to an experimental correction of these estimates, as is the case for Fournier and Potter's equation [29] through the inclusion of the concentration value of Magnesium $(\mathrm{Mg})$, especially temperature estimates above 70 Celsius.

The reason behind correcting the geothermal equations and measures is that the hot aquifer might be formed from an admixture of several groundwater sources that have leaked from different depths or layers, but their mineral elements have not balance after the admixture. This correction is related to the estimates of the above indicator and its relation with the amount of Magnesium (the equation in liters eq/1):

$$
R=M g /(M g+C a+K) * 100(e q) .
$$

The overall objective from this comparison and correction is to know how accurate and valid these different chemical indicators are, and to deduce the general trends derived from them, because the temperature that we estimated in Assammaqieh well might not exceed this level, and therefore many estimated results 
$\mathrm{Mg} / \mathrm{K}^{2}(\mathrm{~mol} / \mathrm{Kgw})$ Michard(1990)

k/Mg(ppm) Giggenbach(1988)

$\mathrm{Mg} / \mathrm{k}^{2}(\mathrm{ppm})$ Giggenbach et all.(1983)

$\mathrm{Na} / \mathrm{K}(\mathrm{mol} / \mathrm{l})$ Fournier et truesdell...

$\mathrm{Na}-\mathrm{K}-\mathrm{Ca}$ Benjamin et al.(1983)

$\mathrm{Na} / \mathrm{K}(\mathrm{mol} / \mathrm{l})$ fournier et truesdell...

$\mathrm{Na} / \mathrm{K}(\mathrm{ppm})$ fournier (1979)

$\mathrm{Na} / \mathrm{K}(\mathrm{mol} / \mathrm{l})$ Michsrd(1990)

$\mathrm{Na} / \mathrm{K}(\mathrm{mol} / \mathrm{l})$ fournier et truesdell... $\mathrm{Na} / \mathrm{K}(\mathrm{ppm})$ ArnÓrsson et all. (1983)

$\mathrm{Na} / \mathrm{K}(\mathrm{mol} / \mathrm{l})$ Michard(1979)

$\mathrm{Na} / \mathrm{K}(\mathrm{mol})$ Tanani (1980)

$\mathrm{Na} / \mathrm{K}(\mathrm{mol} / \mathrm{l})$ Michard(1990)

$\mathrm{Na} / \mathrm{K}(\mathrm{ppm})$ Nieva et Nieva et all. (1987) $\mathrm{Na} / \mathrm{K} / \mathrm{Ca}(\mathrm{mol} / \mathrm{l})$ Fournier et Truesdell ... $\mathrm{Na} / \mathrm{K}(\mathrm{ppm})$ Kharaka et Mariner(1989)

$\mathrm{Na} / \mathrm{K}(\mathrm{mol} / \mathrm{l})$ fournier (1979)

$\mathrm{Na} / \mathrm{K}(\mathrm{ppm})$ fournier (1980)

Benjamin et al.(1983)

$\mathrm{Na} / \mathrm{K}(\mathrm{ppm})$ ArnÓrsson et al. (1984)

$\mathrm{Na} / \mathrm{K}(\mathrm{mol} / \mathrm{l})$ Giggenbach et al.(1983)

$\mathrm{Na} / \mathrm{K}(\mathrm{mol} / \mathrm{l})$ Giggenbach et al.(1988)
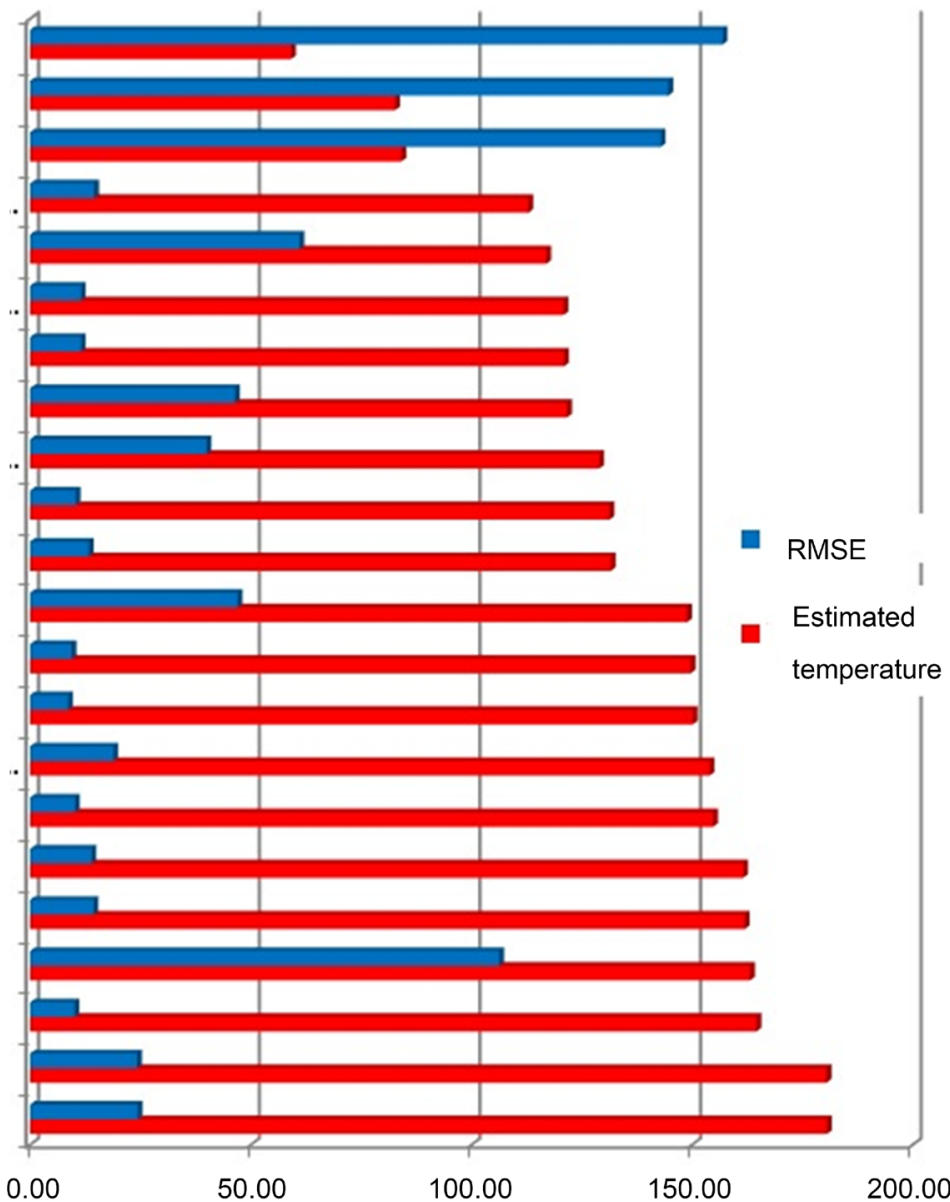

Figure 5. The relation between the estimated temperature and the root mean square error.

were left without modification.

\section{Conclusions}

The laboratory analysis data of Assammaqieh well confirmed that it was warm sulfurous water which acquired its properties from complicated geochemical conditions, and that the geothermometric methods could theoretically and scientifically identify, for the first time in Lebanon, the temperature of an aquifer at a depth between $500-700 \mathrm{~m}$.

It also turned out that the underground heating process was basically due to thermal conductivity and rock adjacency, and that Assammaqieh well was supplied with water from adjacent groundwater tables whose source was the penetration of surface water.

It also appeared that most of the equations used in the search for geothermal energy revealed the presence of an aquifer of hot and very hot water with an arithmetic average (structural) not less than 135 Celsius.

It also appeared that the geothermal equations based on Calcium and Potassium were the least deviated and the most proximate between the actual measurements 


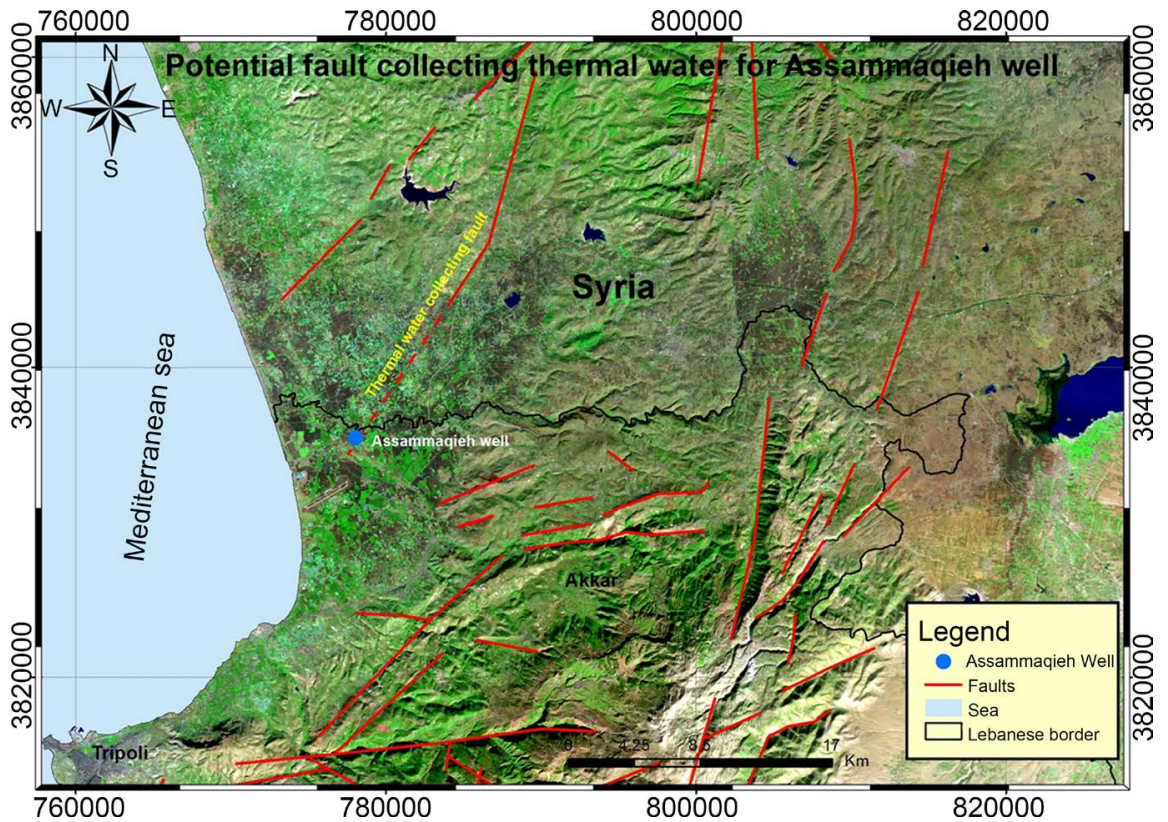

(a)

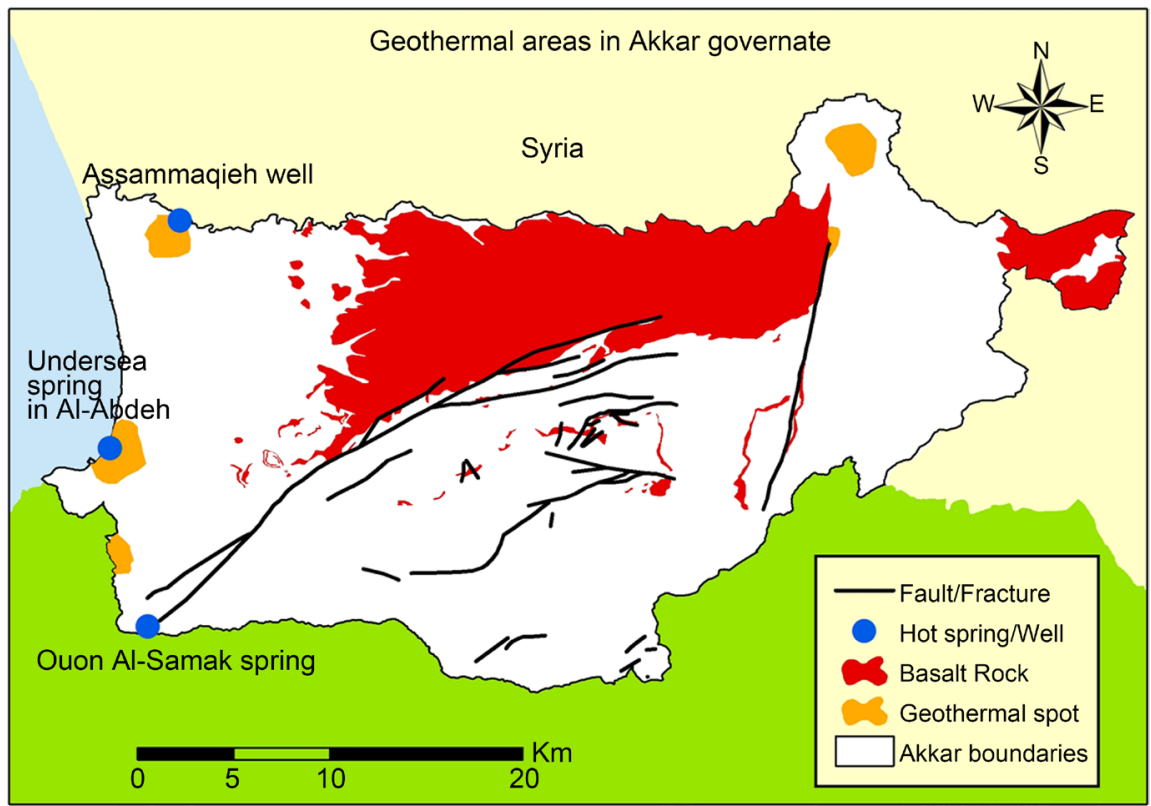

(b)

Figure 6. (a) Potential fault collecting thermal water for Assamaqieh well. (b) Map of geothermal areas in Akkar.

and theoretical values. The estimates of Assammaqieh aquifer temperature tend to use the equations with the highest temperature and little standard deviation of the theoretical estimates, to reach more than 150 Celsius (with the need to take into account 20 Celsius increase or decrease).

It also turned out that this estimate of the geothermal temperature was compatible with the high thermal gradient in volcanic rocks, which was nearly 20 Celsius to every $100 \mathrm{~m}$ in the case of Assammaqieh well. Hence, the deep geothermal beneath Assammaqieh is a residual temperature from periods of lava flow of volcanic 


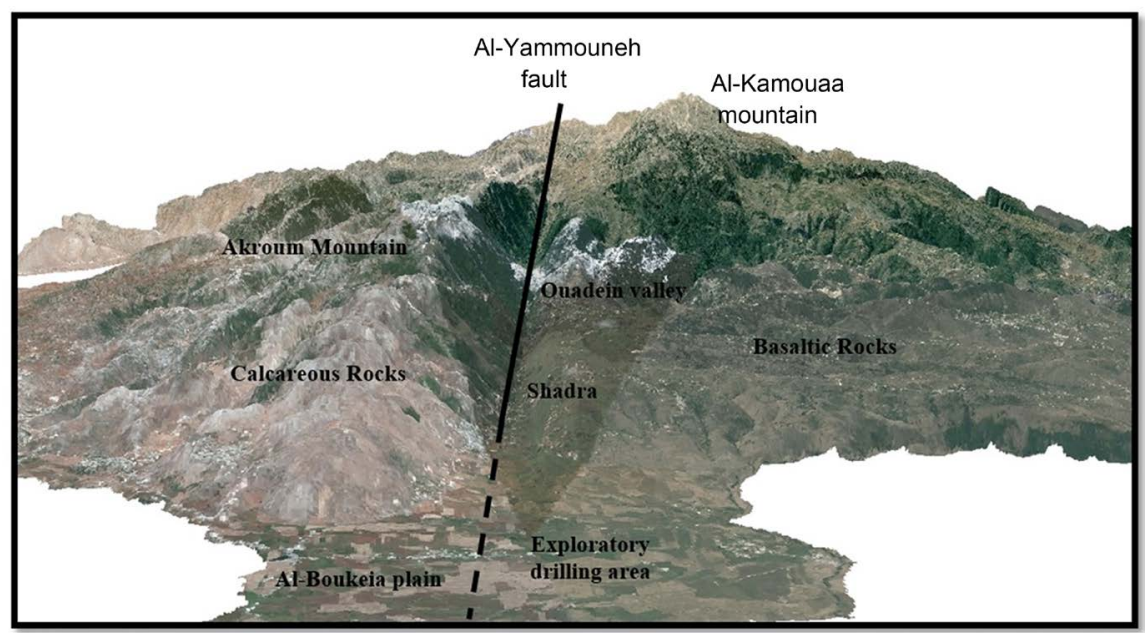

Figure 7. A 3D map of Al-Dreib Al-Aala area in Akkar; the most important geothermal area in Lebanon.

rocks, more than 1.5 million years ago. The source of these basalt lava streams came from the effect of the presence of Al-Yammouna fault and the different folds and faults resulting from it, and from which a group of valleys were formed including Oudeen valley and Shadra area, and emerged consequently from the secondary fractures. Accordingly, these mentioned areas might be the most suited to search for geothermal energy and conduct exploratory excavations.

\section{Acknowledgements}

I would like to extend my appreciation to the Lebanese University for funding this study in the framework of the Scientific Research Support Program.

\section{References}

[1] Serra, H. and Sanjuan, B. (2004) Synthèse bibliographique des géothermomètres chimiques appliqués aux eaux géothermales (rapport final). BRGM, France.

[2] Houri, A. (2005) Renewable Energy Sources in Lebanon: Practical Applications. ISESCO Science and Technology Vision, 1, 65-68.

[3] GLA (2007) Status and Potentials of Renewable Energy Technologies in Lebanon and the Region (Egypt, Jordan, Palestine, Syria). Desk Study Complied by Green Line Association.

[4] Shaban, A. (2010) Geothermal Water in Lebanon: An Alternative Energy Source. National Council for Scientific Research, Remote Sensing Center, Beirut, Lebanon.

[5] Shaban, A. (2010) Geothermal Water in Lebanon: An Alternative Energy Source. Low Carbon Economy, 1, 18-24. https://doi.org/10.4236/lce.2010.11003

[6] Shaban, A. and Khalaf-Kairouz, L. (2012) Preliminary Geological Prospects on the Geothermal Water in Lebanon. International Conference on Renewable Energies for Developing Countries, Beirut, 28-29 November 2012, 1-5. https://doi.org/10.1109/redec.2012.6416712

[7] Shaban, A. and Khalaf-Keyrouz, L. (2013) The Geological Controls of Geothermal Groundwater Sources in Lebanon. International Journal of Energy and Environment, 4, 787-796.

[8] UNDP (2014) The National Geothermal Resource Assessment of LEBANON. 


\section{UNDP/CEDRO.}

http://www.lb.undp.org/content/dam/lebanon/docs/Energy\%20and\%20Environme nt/Publications/National\%20Geothermal\%20Resource\%20Assessment\%20Report.p df

[9] Fournier, R.O. and Truesdell, A.H. (1973) An Empirical Na-K-Ca Geothermometer for Natural Waters. Geochimica et Cosmochimica Acta, 37, 1255-1275. https://doi.org/10.1016/0016-7037(73)90060-4

[10] Weill, D. and Bottinga, Y. (1970) Thermodynamic Analysis of Quartz and Cristobalite Solubilities in Water at Saturation Vapor Pressure. Contributions to Mineralogy and Petrology, 25, 125-132. https://doi.org/10.1007/BF00389780

[11] D’Amore, F. (1987) Stable Isotope Study of Reinjection Processus in the Larderello Geothermal Field. Geochimica et Cosmochimica Acta, 51, 875-867. https://doi.org/10.1016/0016-7037(87)90099-8

[12] Fournier, R.O. (1977) Chemical Geothermometers and Mixing Models for Geothermal Systems. Geothermics, 5, 41-50. https://doi.org/10.1016/0375-6505(77)90007-4

[13] White, D.E. (1968) Saline Waters of Sedimentary Rocks. In: Young, A. and Galley, J.E., Eds., Fluids in Subsurface Environments, AAPG Memoir 4, 342-366.

[14] Ellis, A.J. (1969) Present-Day Hydrothermal Systems and Mineral Deposition. Ninth Common-Wealth Mining and Metallurgical Congress, Mining and Petroleum Geology Sect. Paper 7, 30 p.

[15] Ellis, A.J. (1970) Quantitative Interpretation of Chemical Characteristics of Hydrothermal Systems. Geothermic, 2, 516-528. https://doi.org/10.1016/0375-6505(70)90050-7

[16] Kharaka, Y.K. and Mariner, R.H. (1989) Chemical Geothermometers and Their Applications to Waters from Sedimentary Basins. In: Naeser, N.D. and McCulloh, T.H., Eds., Thermal History of Sedimentary Basins, Springer, Hoboken, 99-117. https://doi.org/10.1007/978-1-4612-3492-0_6

[17] Michard, G. (1979) Chimie des eaux naturelles. Principes de géochimie des eaux. $445 \mathrm{p}$.

[18] Michard, G. (1990) Behaviour of Major Elements and Some Trace Elements (LI, Rb, Cs, Sr, Fe, Mn, W, F) in Deep Hot Waters from Granitis Areas. Chemical Geology, 89, 117-134. https://doi.org/10.1016/0009-2541(90)90062-C

[19] Fournier, R.O. (1979) A Revised Equation for the Na/K Geothermometer. Geothermal Resources Council, 3, 221-224.

[20] Fournier, R.O. (1980) Application of Water Geochemistry of Geothermal Explorating and Reservoir Engineering. In: Rybach, L. and Muffler, L.J.F., Eds., Geothermal Systems: Principles and Case Histories, Wiley, Hoboken, 109-143.

[21] ArnÓrsson, S. (2000) The Quartz and Na/k Geothermometers. I. New Thermodynamic Calibration. Proceedings World Geothermal Congress, Tohoku, 28 May-10 June 2000, 929-934.

[22] Nieva, D. and Nieva, R. (1987) Developments in Geothermal Energy in Mexico Part 12. A Cationic Composition Geothermometer for Prospecting of Geothermal Resources. Heat Recovery Systems and CHP, 7, 243-258. https://doi.org/10.1016/0890-4332(87)90138-4

[23] Giggenbach, W.F., Gonfiantini, R., Janji, B.L. and Truesdell, A.H. (1983) Isotopic and Chemical Compotitions of Parbati Valley Geothermal Discharges, Northwest Himalaya, India. Geothermics, 12, 199-222. https://doi.org/10.1016/0375-6505(83)90030-5

[24] Giggenbach, W.F. (1988) Geothermal Solute Equilibria. Derivation of Na-k-Mg-Ca 
Geoindicators. Geochimica et Cosmochimica Acta, 52, 2749-2765. https://doi.org/10.1016/0016-7037(88)90143-3

[25] Tonani, F. (1980) Some Remarks on the Application of Geochemical Techniques in Geothermal Exploration. Proceedings of the 2 nd International Seminar on the Results of EC Geothermal Energy Research, Strasbourg, 4-6 March 1980, 428-443. https://doi.org/10.1007/978-94-009-9059-3_38

[26] Benjamin, T., Charles, R. and Vidale, R. (1983) Thermodynamic Parameters and Experimental Data for the Na-K-Ca Geothermometer. Journal of Volcanology and Geothermal Research, 15, 167-186. https://doi.org/10.1016/0377-0273(83)90099-9

[27] Han, W. (1979) A Preliminary Evaluation of Geothermal Potential of Korea with Emphasis on Geothermometer and Mixing Model. The Journal of the Geological Society of Korea, 15, 259-268.

[28] Lemale, J. (2012) La géothermie. Dunod, Paris.

[29] Fournier, R.O. and Potter, R.W. (1979) Magnesium Correction the Na-K-Ca Chemical Geothermometer. Geochimica et Cosmochimica Acta, 43, 11543-11550. https://doi.org/10.1016/0016-7037(79)90147-9

Submit or recommend next manuscript to SCIRP and we will provide best service for you:

Accepting pre-submission inquiries through Email, Facebook, LinkedIn, Twitter, etc. A wide selection of journals (inclusive of 9 subjects, more than 200 journals) Providing 24-hour high-quality service User-friendly online submission system Fair and swift peer-review system Efficient typesetting and proofreading procedure Display of the result of downloads and visits, as well as the number of cited articles Maximum dissemination of your research work

Submit your manuscript at: http://papersubmission.scirp.org/ Or contact jwarp@scirp.org 